\title{
Control of synthesis and positioning of a Caulobacter crescentus flagellar protein
}

\author{
Zvi G. Loewy, ${ }^{1}$ Ruth A. Bryan, ${ }^{2}$ Sandra H. Reuter, ${ }^{2}$ and Lucille Shapiro ${ }^{2}$ \\ ${ }^{1}$ Albert Einstein College of Medicine, Department of Molecular Biology, Bronx, New York 10461 USA $^{2}$ Department of \\ Microbiology, College of Physicians and Surgeons of Columbia University, New York, New York 10032 USA
}

\begin{abstract}
The Caulobacter crescentus flagellum is assembled during a defined time period in the cell cycle. Two genes encoding the major components of the flagellar filament, the $25 \mathrm{~K}$ and the $27.5 \mathrm{~K}$ flagellins, are expressed coincident with flagellar assembly. A third gene, flgI, is also temporally regulated. The synthesis of the product of $f l g J$, the $29 \mathrm{~K}$ flagellin, occurs prior to the synthesis of the other flagellin proteins. We demonstrate here that the time of initiation of $\mathrm{flg} /$ expression is independent of chromosomal location but is dependent upon cisacting sequences present upstream of the flgJ structural gene. Evidence that there is transcriptional control of flgJ expression includes the following: (1) The initial appearance of flgJ message was coincident with the onset of $29 \mathrm{~K}$ flagellin protein synthesis, and (2) expression of an NPT II reporter gene driven by the flgJ promoter was temporally correct. Post-transcriptional regulation might contribute to the control of expression, because the flgI mRNA persisted for a longer period of time than did the synthesis of the $29 \mathrm{~K}$ protein. The $29 \mathrm{~K}$ flagellin was found only in the progeny swarmer cell after cell division. In a mutant strain that failed to assemble a flagellum, the $29 \mathrm{~K}$ flagellin still segregated to the presumptive swarmer cell, demonstrating that positioning of the protein is independent of filament assembly. Analysis of a chimeric flgJ-NPT II transcriptional fusion showed that the flgI regulatory sequences do not control the segregation of the $29 \mathrm{~K}$ flagellin to the swarmer cell progeny, suggesting that correct segregation depends on the protein product.
\end{abstract}

[Key Words: Caulobacter crescentus; flagellar protein; flg/ expression]

Received April 27, 1987; revised version accepted June 4, 1987.

The Caulobacter crescentus flagellum and chemotaxis apparatus are only present transiently during the cell cycle. A single polar flagellum is synthesized just prior to cell division; consequently, only one daughter cell carries a flagellum. The flagellum is a complex structure containing three subassemblies: a basal body, a hook, and a filament (Johnson et al. 1979; Wagenknecht et al. 1981; Stallmeyer et al. 1985). Over 30 flagellar (fla) genes involved in the biogenesis of this structure have been identified, and an additional 11 genes are required for motility and chemotaxis (Ely et al. 1984, 1986). The genes for the filament include a cluster containing $\mathrm{flgJ}$ (29K flagellin), flgK (25 flagellin), and flgL (27.5K flagellin). An additional three genes encoding $25 \mathrm{~K}$ flagellins are located elsewhere on the chromosome $(\mathrm{N}$. Agabian, unpubl.). The gene encoding the hook protein flaK resides in a separate cluster of fla genes (Chen et al. 1986).

All flagellar and chemotaxis proteins that have been identified have been found to be synthesized at a specific time in the cell cycle, with the peak of synthesis occurring around the time of flagellar assembly. Evidence has been presented suggesting that the time of expression of

${ }^{2}$ Corresponding author. the Caulobacter flagellar genes is regulated at the transcriptional level and that the amount of flagellar and chemotaxis gene expression is modulated by a transacting cascade of fla gene products (Champer et al. 1985, 1987; Chen et al. 1986). The mechanisms that control the time of fla gene expression appear to function independently of the regulatory cascade that controls the amount of gene expression (Bryan et al. 1987).

The assembly of the flagellum at one pole of the predivisional cell requires that the newly synthesized flagellar proteins be sequestered to a specific cellular location. The proteins involved in chemotaxis are also positionally biased to the flagellar pole of the predivisional cell and are segregated to the swarmer cell progeny upon division (Gomes and Shapiro 1984; Nathan et al. 1986). Thus, the biogenesis of the flagellum and chemotaxis apparatus depends on complex regulatory signals that control the time of synthesis, the amount of synthesis, and the positioning of a large number of flagellar and chemotaxis proteins within the cell.

To identify the regulatory signals that control the temporal and spatial expression of a specific fla gene, we have studied the expression of the flg/ gene. flg/ encodes a 29K flagellin (Gill and Agabian 1983) that is part of a family of differentially expressed flagellins (Lagenaur 
and Agabian 1978). The two other flagellins, $27.5 \mathrm{~K}$ and $25 \mathrm{~K}$, comprise the major portion of the flagellar filament, with the $27.5 \mathrm{~K}$ protein occupying the hook-proximal position (Koyasu et al. 1981; Weissborn et al. 1982). The $\mathrm{flg} / \mathrm{gene}$ has been isolated (Milhausen et al. 1982; Purucker et al. 1982) and sequenced (Gill and Agabian 1983). Lagenaur and Agabian (1978) have shown that the $29 \mathrm{~K}$ flagellin is synthesized prior to the synthesis of the $27.5 \mathrm{~K}$ and $25 \mathrm{~K}$ flagellins. We show here that the timing of transcription of $\mathrm{flg} /$ is dependent on nucleotide sequences in the 5'-regulatory region of the gene and that this temporal control is independent of whether the gene is located on the chromosome or on a low-copynumber plasmid. We also provide evidence that the protein-coding portion of the $f l g /$ gene is necessary for the segregation of the $29 \mathrm{~K}$ product to only one of the progeny cells (the swarmer cell). The correct segregation of this protein to the swarmer cell occurs in mutants unable to assemble a flagellum. Therefore, the signals that contribute to the positioning of the protein appear to be independent of the flagellar assembly process.

\section{Results}

Temporal expression of the flgJ gene from chromosomal or plasmid locations

The time of synthesis of the three flagellins in synchronized cells was determined by immunoprecipitation of $\left.{ }^{35} \mathrm{~S}\right]$ methionine pulse-labeled cultures with anti-flagellin antibody (Fig. 1). The polyclonal anti-flagellin antibody cross-reacts with all three flagellin species because the amino acid sequence of these proteins has been highly conserved (Gill and Agabian 1982; Weissborn et al. 1982).

Analysis of wild-type cultures showed that the $25 \mathrm{~K}$ flagellin is synthesized in the swarmer cell after cell division (Fig. 1A). Following differentiation of the swarmer cell into a stalked cell, the $29 \mathrm{~K}$ flagellin is the first flagellin made, followed by the $27.5 \mathrm{~K}$ flagellin and the $25 \mathrm{~K}$ flagellin. This temporal order of synthesis reflects the position of these flagellins in the filament. Recently, we have been able to detect the $29 \mathrm{~K}$ flagellin in a very short hook-proximal region of the filament using immunomicroscopy (A. Driks and R. Bryan, unpubl.). The rest of the hook-proximal portion of the filament is composed of the $27.5 \mathrm{~K}$ flagellin, and the remainder of the filament, by the 25K flagellin (Koyasu et al. 1981; Weissborn et al. 1982). The onset of synthesis of the $29 \mathrm{~K}$ flagellin occurred at 0.5 division units, and its synthesis was detected for only a brief period, prior to the onset of flagellar assembly (Fig. 1A).

To determine whether the temporal expression of the flg/ gene was dependent on its chromosomal location, a strain, AE9002 (Table 1), was constructed in which the $\mathrm{flg} / \mathrm{gene}$ was deleted from the chromosome. A plasmid, pRB3, containing $f l g /$ (Fig. 2A) was then mated into the deletion strain. Details of the strain construction and mapping of the deletion are described in Materials and methods. As shown in Figure 2A, AE9002 contains a deletion of $f l g l, f l a E$, and part of $f l a Y$, as well as a portion of

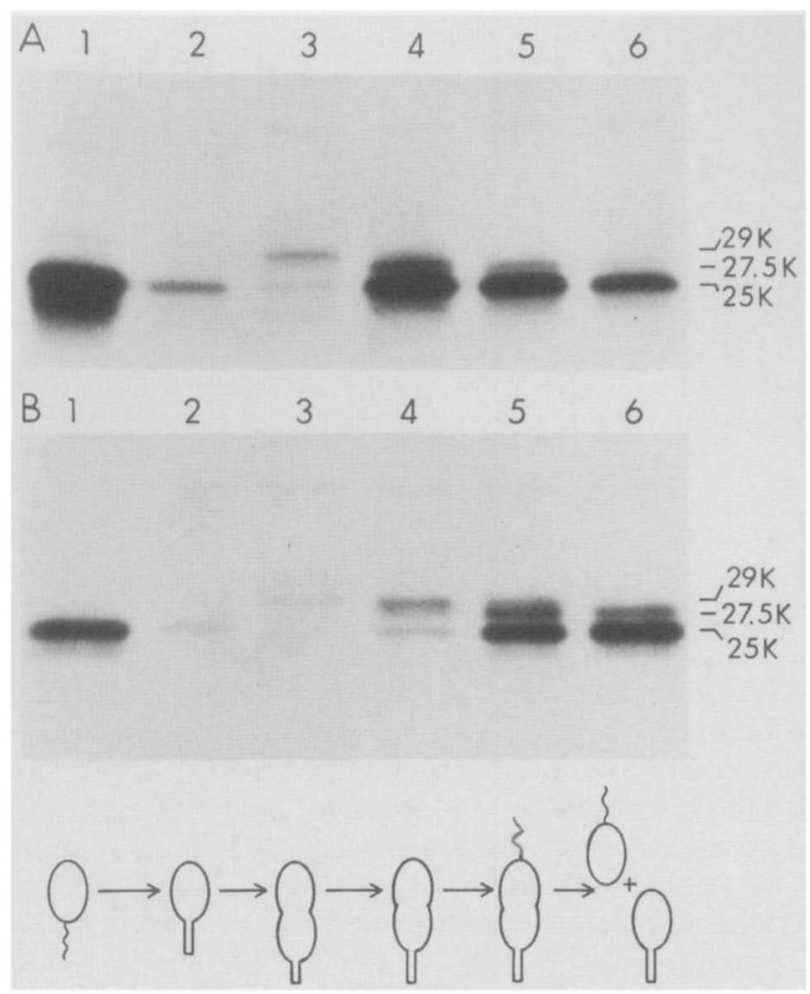

Figure 1. The time of synthesis of the three flagellins during the $C$. crescentus cell cycle. Aliquots of synchronized cultures of wild-type CB15N $(A)$ and AE9002/pRB3 $(B)$ were pulse-labeled for $10 \mathrm{~min}$ with $\left.{ }^{35} \mathrm{~S}\right]$ methionine $(15 \mu \mathrm{Ci})$ at specific stages in the cell cycle, indicated by the schematic shown below $B$. Proteins were immunoprecipitated with anti-flagellin antibody, as described in Materials and methods, and then separated by electrophoresis through a $10 \%$ polyacrylamide-SDS gel. Autoradiograms of the separated proteins are shown, and the $29 \mathrm{~K}$, $27.5 \mathrm{~K}$, and $25 \mathrm{~K}$ flagellins are indicated. Aliquots of cells were pulse-labeled at $0,0.2,0.5,0.6,0.75$, and 1.0 division units, and the immunoprecipitated proteins are shown in lanes $1-6$, respectively. Division units represent fractions of the cell-division cycle, with 1 unit equivalent to the generation time. The generation time of these cultures, grown in minimal glucose M2 media, was $160 \mathrm{~min}$.

$f l g K$, one of the structural genes for the $25 \mathrm{~K}$ flagellin (Minnich and Newton 1987). The plasmid pRB3, containing intact flgJ, flaE, and flaY genes, as well as a portion of the flgK gene, was mobilized from Escherichia coli HB101 into AE9002. The presence of pRB3 enabled AE9002 to swim and allowed the synthesis of all three flagellins (Fig. 2B, lane 3). AE9002 carrying the plasmid pRB7 (Fig. 2A), with just the flaE and flaY genes, was able to swim but failed to synthesize the $29 \mathrm{~K}$ flagellin (Fig. 2B, lane 2). Thus, the 29K flagellin does not appear to be required for motility, nor does motility appear to depend on the synthesis of the $25 \mathrm{~K}$ flagellin encoded by flgK. Although $f l g I$ is the only gene encoding the $29 \mathrm{~K}$ flagellin, there is another group of $25 \mathrm{~K}$ flagellin genes elsewhere on the chromosome (Gill and Agabian 1983).

To ascertain whether the flg/ gene on pRB3 had maintained its plasmid location, motile cells were selected by streaking AE9002/pRB3 twice onto a swarmer agar plate. 
Table 1. Bacterial strains

\begin{tabular}{cll}
\hline Strain & Genotype & Source/derivation/reference \\
\hline (a) C. crescentus & & \\
AE5000 & wild-type & Poindexter (1964) \\
CB15N & wild-type, synchronizable & Evinger and Agabian (1977) \\
AE5478 & cysD:: Tn5, ts104/pVS1 & David Hodgson \\
AE9001 & cysD : Tn5 in CB15N/pVS1 & AE5478 $\times$ CB15N \\
SC512 & flaE156 & Johnson and Ely (1979); Purucker et al. (1982) \\
AE9002 & flaE156 in CB15N & 0CR30-mediated transduction of AE9001 $\times$ SC512; \\
& cured of pVS1 \\
AE8006 & $f l a K::$ Tn5-VB32 & Champer et al. (1987) \\
SC1997 & $f l a N::$ Tn5 & Bryan et al. (1987) \\
(b) E. coli & & \\
HB101 & $\mathrm{rB}^{-}, \mathrm{mB}^{-}$, recA13, suII, leuB6, B1- & \\
& proA2, lacZ4, Sm ${ }^{\mathrm{R}}$ & Cold Spring Harbor Laboratory \\
\hline
\end{tabular}

Cells from the border of the swarm were propagated, and DNA was isolated for Southern blot analysis. The DNA was digested with the restriction enzymes HindIII and BamHI and analyzed by Southern blot hybridization using as probe the nick-translated EcoRI-BamHI (probe 1) fragment shown in Figure 2A. If the plasmid pRB3 recombined into the chromosome between the left EcoRI site and the left end of the deletion, the flgK gene would be restored, and flg/ would be restored to its chromosomal location between $f l g K$ and $f l a E$. Evidence of this event would be the restoration of the HindIII and BamHI fragments found in wild-type DNA. There was no evidence that this recombination event had occurred /data not shown). The only bands visible following Southern blot hybridization using the probes shown in Figure 2A demonstrated that the chromosomal deletion was still present and that this recombination event had not occurred. If the plasmid recombined into the chromosome between the right end of the deletion and the right EcoRI site, a pattern of hybridization indistinguishable from that obtained without recombination would be obtained, but the chromosomal order of $f l g K, f l g I$, and flaE genes would not be restored.

Having determined that $f l g /$ in AE9002/pRB3 had not regained its wild-type chromosomal location, we synchronized cultures of this strain. At various times in

Figure 2. $(A)$ Restriction map of a region of the C. crescentus $\mathrm{CB} 15$ chromosome carrying the $f l g l$, flaE, and flaY genes. The boxed portion shows the location and extent of the chromosomal deletion in AE9002. The extent of the pRB3 insert containing part of $f l g K$ ( $25 \mathrm{~K}$ flagellin), as well as the $f l g J(29 \mathrm{~K}$ flagellin), flaE, and flaY genes, and the pRB7 insert containing the flaE and flaY genes are shown, as are the probes used for Southern hybridization. The restriction enzymes used were BamHI (B), HindIII (H), EcoRI (E), PstI (P), and SalI (S). (B) Flagellin composition of the deletion strain AE9002 containing pRK290 vector (1), pRB7 (2), or pRB3 (3). The flagellins were detected by immunoprecipitation of ${ }^{35} \mathrm{~S} \mid$ methionine pulse-labeled cultures with anti-flagellin antibody. The immunoprecipitated proteins were separated by electrophoresis through $10 \%$ polyacrylamide-SDS gels. the cell cycle, aliquots were pulse-labeled with $\left[{ }^{35} \mathrm{~S}\right] \mathrm{me}$ thionine, and the cell extracts were immunoprecipitated with flagellin antisera (Fig. 1B). As expected from the partial deletion in one of the $25 \mathrm{~K}$ flagellin genes, the level of the $25 \mathrm{~K}$ flagellin was lower in these cells. The amount of the $29 \mathrm{~K}$ flagellin was elevated relative to the level found in wild type (Fig. 1A), probably due to plasmid copy number lapproximately five copies per cell). The time of initiation of synthesis of the $29 \mathrm{~K}$ protein, however, was the same as in wild-type cells, demonstrating that the signals that control timing are present in pRB3. These results also suggest that the gene
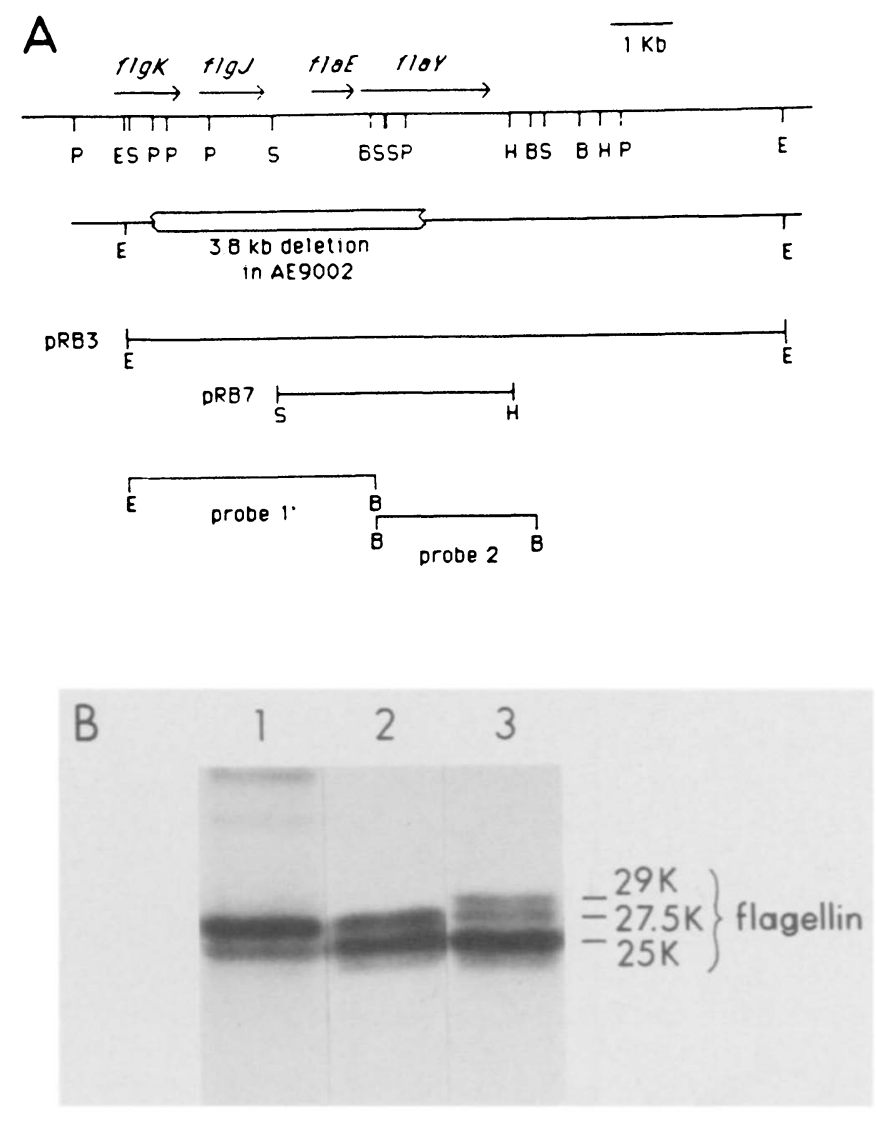
does not have to be located on the chromosome for correct temporal control.

\section{Cell-cycle expression of flgJ $m R N A$}

The time of appearance of the $f l g /$ mRNA was measured in synchronous cultures of AE9002/pRB3, using an S1 nuclease protection assay (Fig. 3). A 280-base NaeI-TaqI fragment was labeled at the $5^{\prime}$ end and used as the probe (Fig. 3A). The size of the RNA fragment protected by hybridization to the NaeI-TaqI DNA fragment should be approximately 180 bases in length. A protected fragment of that size was first detected at 0.5 cell-cycle division units (Fig. 3B). Therefore, the time of initiation of $f l g I$ mRNA synthesis coincided with the time of initiation of synthesis of the $29 \mathrm{~K}$ flagellin. The mRNA fragment was still detected, although at decreased abundance, at 1.0 division units. The time of expression of $f l g /$ mRNA was found to be the same in wild-type CB15N cells, using the PvuII-ClaI probe shown in Figure 3A. The PvuII-ClaI probe was also used in S1 protection assays with RNA extracted from AE9002/pRB3 at various times in the cell cycle (data not shown). This experiment confirmed the time of appearance and duration of the $f l g /$ mRNA protected by the NaeI-TaqI probe.

Temporal regulation of a chimeric mRNA composed of the flgJ $5^{\prime}$ region and the protein-coding sequence for neomycin phosphotransferase II

The promoter region and $340 \mathrm{bp}$ of the coding region of the $f l g I$ gene were subcloned into the promoter probe vector pZL250, which contained a promoterless neomycin phosphotransferase II (NPT II) structural gene (Fig. 4). The presence of a translational stop codon in the reading frame of the $29 \mathrm{~K}$ flagellin gene immediately upstream to the NPT II Shine-Delgarno sequence prevented formation of a protein fusion. Two chimeric plasmids were constructed: pZL1451, in which the flg promoter was inserted in the same transcriptional direction as the promoterless NPT II gene, and pZL1452, in which the flg/ promoter was inserted in the opposite direction (Fig. 4). The expression of NPT II in C. crescentus strains containing these plasmids was assayed in two ways: (1) The concentration of kanamycin, at which cells containing the chimeric plasmids could grow, was measured by replica plating (Table 2); and (2) the synthesis of NPT II in $\left.{ }^{35} \mathrm{~S}\right]$ methionine-labeled cultures was measured by immunoprecipitation with anti-NPT II antibody (Fig. 5). The presence of the plasmid pZL1451 in the wild-type strain $\mathrm{CB} 15 \mathrm{~N}$ conferred resistance to 150 $\mu \mathrm{g} / \mathrm{ml}$ of kanamycin (Table 2). The C. crescentus strain AE9002, in which the flgl, flaE, and flaY genes are deleted, also became resistant to $150 \mu \mathrm{g} / \mathrm{ml}$ kanamycin upon the introduction of pZL1451. NPT II expression was driven by the $f l g I$ promoter and not a promoter present elsewhere on the plasmid, because plasmid pZL1452 was unable to confer resistance to kanamycin in either C. crescentus strain.

Synthesis of NPT II in CB15N/pZL1451 was measured in synchronized cultures to determine whether the $5^{\prime}$ regulatory sequences of $\mathrm{flg} /$ are sufficient to control the
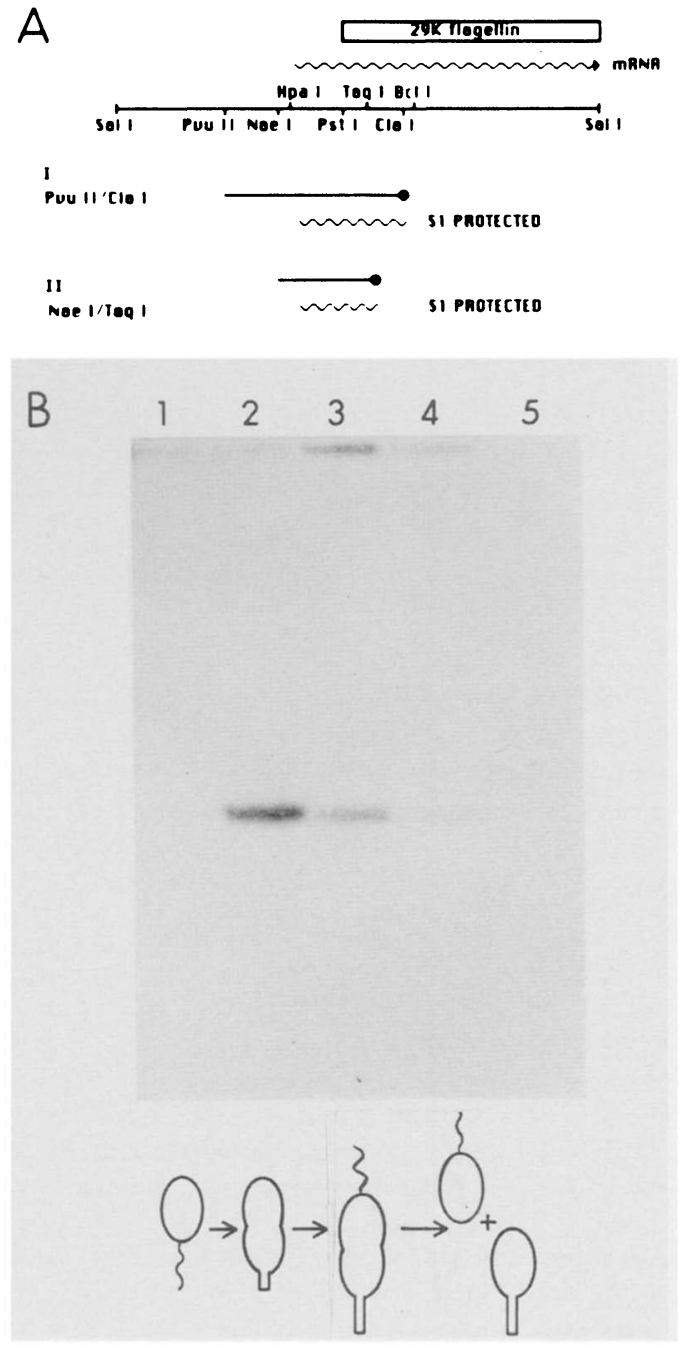

Figure 3. Nuclease $S 1$ protection assays of $f l g /$ transcripts as a function of the cell cycle. $(A)$ Schematic representation of nuclease $\mathrm{S} 1$ analysis. (Top) A partial restriction map of the $5^{\prime}$ region and the protein-coding sequence of the flgI gene. The restriction fragments used as probes are indicated by a solid line below the restriction map. The line ends in a dot, which indicates the $5^{\prime}$ end label. The PvuII-ClaI probe is 810 bp in length, and the NaeI-TaqI probe is 280 bp in length. The wavy lines indicate the protected RNA fragment, $280 \mathrm{bp}$ in the first case and $180 \mathrm{bp}$ in the latter case. $(B)$ Cells of strain AE9002/pRB3 were grown in rich PYE media and synchronized as described in Materials and methods. The generation time was $90 \mathrm{~min}$. Aliquots were taken at $0,0.5,0.8$, and 1.0 division unit, shown in lanes $1-4$, respectively. Lane 5 is a control of the probe and S1 without any RNA. RNA was purified as described previously (Amemiya et al. 1980). The level of $f l g /$ mRNA in each sample was determined by $\mathrm{S} 1$ nuclease assays with the NaeI-TaqI probe, as described in Materials and methods. Samples were separated by electrophoresis in a $6 \%$ polyacrylamide/urea gel.

temporal expression of the NPT II-coding region (Fig. 5B). Immunoprecipitation of pulse-labeled synchronized cells (Fig. 5B) showed that NPT II first appeared at 0.5 division units, reached a maximum at 0.75 division units, and then diminished as the culture approached cell division. This onset of synthesis of NPT II occurred 


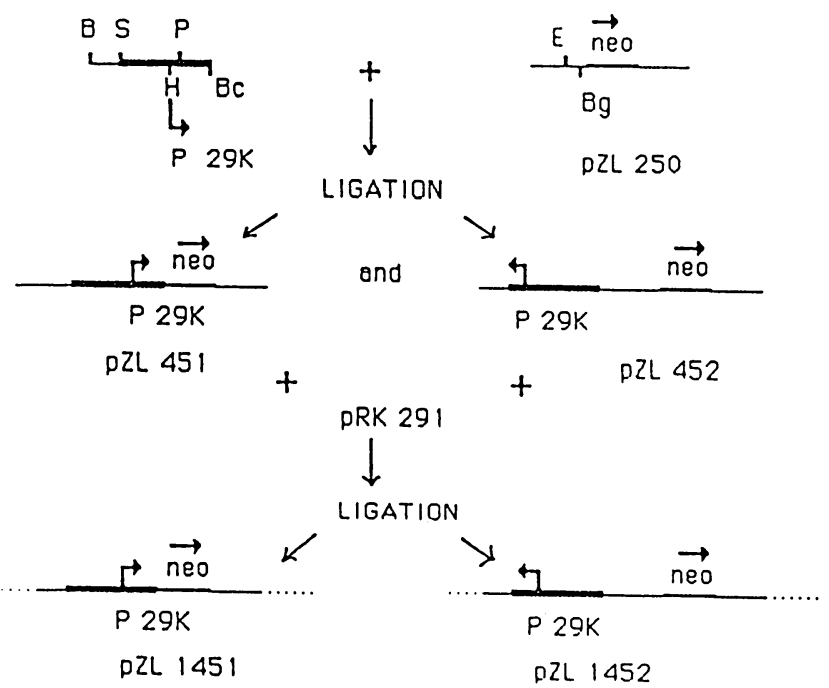

Figure 4. Schematic diagram showing the construction of a chimeric plasmid containing the promoter and amino-terminal sequences of $f l g l$ in a transcription fusion with the gene encoding NPT II. A 1.7-kb BamHI-Bcll fragment, derived from a fusion of the small BamHI-Sall fragment from pBR322, and a 1.4-kb SalI-BclI fragment of $C$. crescentus sequences, containing 340 nucleotides of the $\mathrm{flg} /$-coding region and the entire $5^{\prime}$ regulatory region, was inserted in both orientations into the unique $B g l I I$ site that is immediately upstream to the promoterless neo gene present in pZL250. pZL250 was constructed as described in Materials and methods. pZL451 and pZL452 were inserted into pRK291. The pZL1451 plasmid contains an inframe translation stop signal between the $5^{\prime}$ fragment of the flgI gene and the ATG of the neo gene, ensuring that an intact protein product, NPT II, could be synthesized. pZL1452 contains the $f l g /$ promoter region in opposite orientation with respect to the neo gene. Restriction enzymes used were BamHI (B), Sall $(\mathrm{S}), B c I I(\mathrm{Bc})$, EcoRI $(\mathrm{E})$, and $B g I I I(\mathrm{Bg})$.

at the same time point in the cell cycle as the onset of synthesis of the $29 \mathrm{~K}$ flagellin (Fig. 1). Because NPT II protein synthesis measures the presence of the chimeric mRNA originating at the $f l g /$ promoter, these results are in agreement with the S1 nuclease protection assays of flgI mRNA (Fig. 3B). When the neo gene is driven by its own promoter in a Tn5 insertion mutant, it is constitutively expressed throughout the cell cycle (Champer et al. 1987). These results provide direct evidence that the temporal turn-on of the $f l g l$ gene in the $C$. crescentus cell cycle is controlled by sequences in the $5^{\prime}$ regulatory region of the gene.

\section{Segregation of the $29 \mathrm{~K}$ flagellin to the swarmer cell progeny}

The assembly of the flagellum occurs at one pole of the predivisional cell prior to cell division. Flagellins that were pulse-labeled with $\left[{ }^{35} \mathrm{~S}\right]$ methionine during their synthesis in the predivisional cell were recovered only in the swarmer cell progeny following cell division (Fig. 6A). The autoradiograph shown was overexposed to demonstrate that almost all of the newly synthesized flagellins can be chased into the flagellum-bearing swarmer cell. These results suggest that either all the flagellins are assembled into the filament or both assembled and nonassembled flagellins are segregated to the pole of the predivisional cell prior to division. In strain AE9002/pRB3, in which one of the flagellins, the $29 \mathrm{~K}$ subunit, is somewhat overproduced because the gene resides on a plasmid with a copy number of approximately five, we found that the excess $29 \mathrm{~K}$ flagellin also segregated to the swarmer cell (Fig. 6B). Huguenel and Newton (1984) presented evidence that a pool of free flagellins can be detected in a polar compartment in the predivisional cell. In addition, we have recently shown that the newly synthesized MCP chemotaxis receptor is preferentially inserted into the membrane of the swarmer portion of the predivisional cell (Nathan et al. 1986). These results suggest that some mechanism other than assembly into a complex structure contributes to the positioning of the flagellar and chemotaxis proteins in the predivisional cell and their subsequent segregation to the swarmer cell progeny. This argument is supported by the results of the experiment that shows the segregation pattern of the $29 \mathrm{~K}$ flagellin in a mutant unable to assemble a flagellum (Fig. 6E). The mutant strain AE8006 has a transposon (Tn5-VB32) insertion in the flaK gene that normally encodes the hook protein. Sequence analysis showed that the insertion is at codon 8 of the hook protein structural gene $(\mathrm{H}$. Xu and J. Kaplan, unpubl.). In the absence of a hook protein, neither the hook nor the filament can be assembled. Hook protein null mutations result in a down-regulation of both the $25 \mathrm{~K}$ and the $27.5 \mathrm{~K}$ flagellins and the up-regulation of the 29K flagellin. Pulse-chase experiments with AE8006 show clearly that the $29 \mathrm{~K}$ flagellin, synthesized prior to cell division, segregated to the swarmer progeny cell in this strain, even though it could not be assembled into a filament (Fig. 6E).

Having observed that a given flagellar protein does not have to be assembled into a flagellum to be segregated to the swarmer cell, we can now ask whether the $5^{\prime}$ regulatory region of a gene encoding a "segregated" protein contributes to its correct positioning in the predivisional cell. This question was approached by analyzing the segregation pattern of the foreign protein, NPT II, when its expression is driven by the $5^{\prime}$ regulatory region of the $\mathrm{flgl}$ gene (see Fig. 5A). Cultures of CB15N/pZL1451 were synchronized, and the predivisional cells were pulse-labeled with ${ }^{35} \mathrm{~S} \mid$ methionine. Cell division was allowed to proceed in the absence of label, the progeny cells were separated, and the presence of labeled NPT II was as-

Table 2. Plasmids and kanamycin concentrations that allow growth

\begin{tabular}{lc}
\hline Strain & $\begin{array}{c}\text { Kanamycin } \\
(\mu \mathrm{g} / \mathrm{ml})\end{array}$ \\
\hline CB15N/pZL1451 & 150 \\
AE9002/pZL1451 & 150 \\
CB15N/pZL1452 & $<20$ \\
AE9002/pZL1452 & $<20$ \\
\hline
\end{tabular}



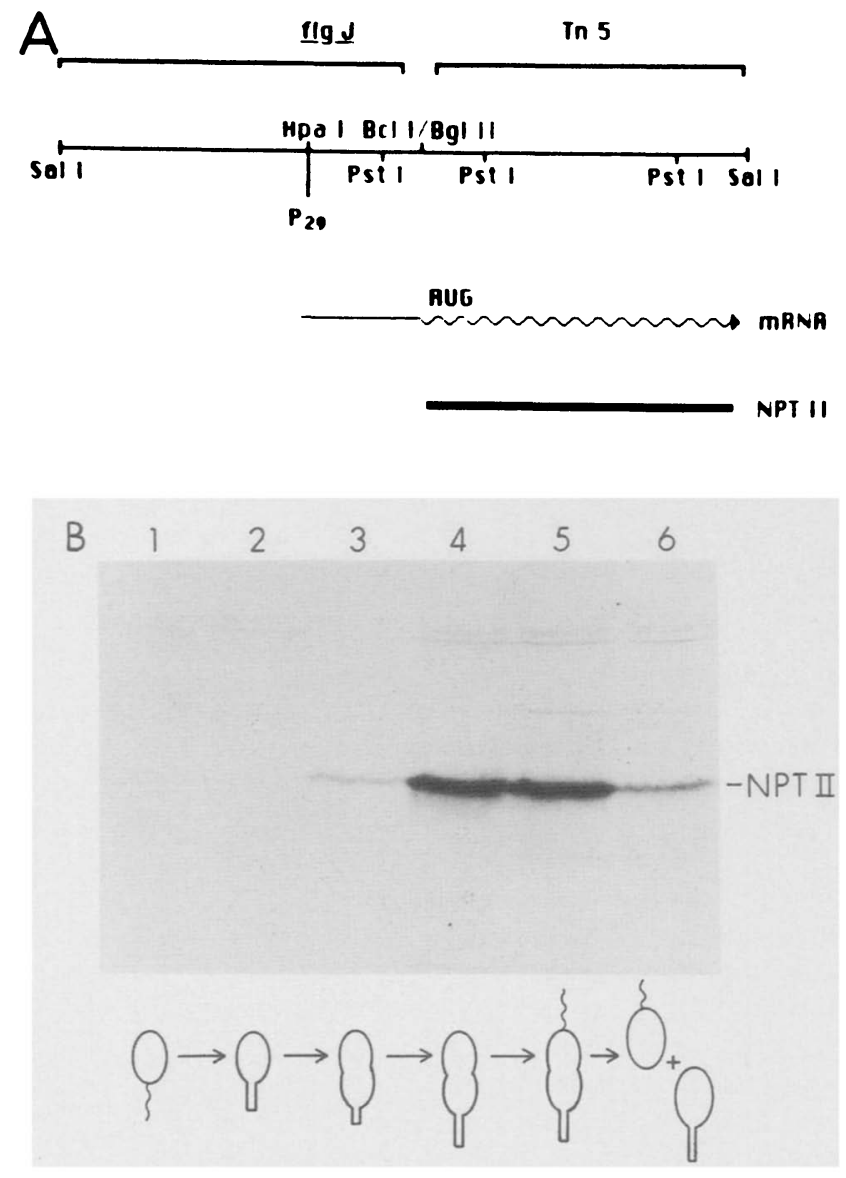

Figure 5. The expression of NPT II from the chimeric flg/-neo gene in the plasmid pZL1451. Cultures of $C$. crescentus CB15N/pZL1451 were synchronized, and the synthesis of NPT II was measured in aliquots of cells pulse-labeled with $\left[{ }^{35} \mathrm{~S}\right] \mathrm{me}$ thionine. Cell extracts were immunoprecipated with anti-NPT II antibody, as described in Materials and methods. (A) A restriction map of the junction between the flg/ promoter, a portion of the $29 \mathrm{~K} 5^{\prime}$-coding region, and the promoterless neo gene. Due to the presence of an in-frame translation stop signal between the $f l g /$ fragment and the neo gene, the chimeric mRNA yields free NPT II. $(B)$ An autoradiogram of a $10 \%$ polyacrylamide-SDS gel, showing the level of synthesis of NPT II at 0 , $0.25,0.5,0.6,0.75$, and 1.0 cell-cycle division units. The culture, grown in minimal glucose M2 media, had a generation time of $140 \mathrm{~min}$. Lanes $1-6$ correspond to the specific stages of the cell cycle shown diagrammatically below the gel.

sayed by immunoprecipitation (Fig. 6C). The NPT was not segregated to the swarmer cell but was found predominantly in the stalked cell progeny. In a control experiment, the segregation pattern of NPT II expressed from its own promoter in an intact Tn5, inserted in a flaE gene, was found to be the same as that found with the chimeric gene encoding NPT II in CB15N/pZL1451 (Fig. 6D). These results imply that the nucleotide sequences responsible for differential expression of the $29 \mathrm{~K}$ flagellin do not contribute to the positioning of the protein within the cell but that the protein product is responsible for its localization.

\section{Discussion \\ Temporal regulation of flagellin gene expression}

The temporal expression of one of the Caulobacter flagellin genes, $f l g J$, as well as the control of the placement of its gene product, the $29 \mathrm{~K}$ flagellin, have been characterized in this study. Our initial experiments confirmed earlier work (Lagenaur and Agabian 1978) that established the time of synthesis of the $29 \mathrm{~K}$ flagellin protein at an early time in the stalked cell cycle relative to the other flagellin proteins. Nuclease S1 protection experiments showed that the initial appearance of the flgI message coincided with the onset of $29 \mathrm{~K}$ flagellin synthesis. When the $29 \mathrm{~K}$ flagellin was expressed from a plasmid in a Caulobacter strain deleted for flg/ on the chromosome, the time of initiation of $f l g /$ mRNA and $29 \mathrm{~K}$ flagellin synthesis remained intact. Thus, the temporal regulation of $f l g J$ expression is independent of its chromosomal location, and all the sequences necessary for temporal control are contained on the cloned DNA fragment with an intact $f l g /$ gene.

A transcription fusion was constructed in which the flgI promoter region drives the reporter gene encoding NPT II. Analysis of strains harboring this chimeric construct showed that NPT II synthesis was initiated at the same time in the cell cycle as the synthesis of the $29 \mathrm{~K}$ flagellin from the intact gene. These results clearly demonstrate that the sequences 5 ' to the structural gene determine the time of initiation of expression of $f l g /$.

The contribution of 5 ' regulatory sequences to cellcycle control has been characterized in a variety of systems. Artishevsky et al. (1985) showed that 5'flanking sequences from a hamster histone $\mathrm{H} 3$ gene were sufficient to regulate bacterial coding sequences in a cell-cycle manner. Recently, Osley et al. (1986) demonstrated that the periodic expression of yeast histone genes was dependent on sequences localized to the $5^{\prime}$ promoter region. Studies from our laboratory (Champer et al. 1985, 1987) showed that a reporter gene encoding NPT II was expressed at the correct time in the cell cycle when placed under the control of promoters for several different temporally regulated flagellar genes.

Although the time of initiation of $f l g / \mathrm{mRNA}$ and protein synthesis was coincident at 0.5 division units, the flgI mRNA persisted after $29 \mathrm{~K}$ flagellin synthesis had ceased. In addition, the synthesis of NPT II from the transcription fusion driven by the $f l g l$ promoter continued after the period of $29 \mathrm{~K}$ flagellin synthesis. These observations suggest that post-transcriptional control might contribute to the temporal regulation of fla-gene expression.

The initiation of synthesis of the hook protein and the $25 \mathrm{~K}$ and $27.5 \mathrm{~K}$ flagellins occurs close to their time of assembly into the flagellar structure. However, the time of synthesis of the $29 \mathrm{~K}$ flagellin occurs relatively early in the cell cycle, prior to the synthesis of other known flagellar components. The early time of synthesis of the $29 \mathrm{~K}$ flagellin suggests that it functions at a relatively early stage in the assembly process. The role of the $29 \mathrm{~K}$ flagellin in the flagellar assembly process is not known. Analysis of the filament structure by immunomicro- 


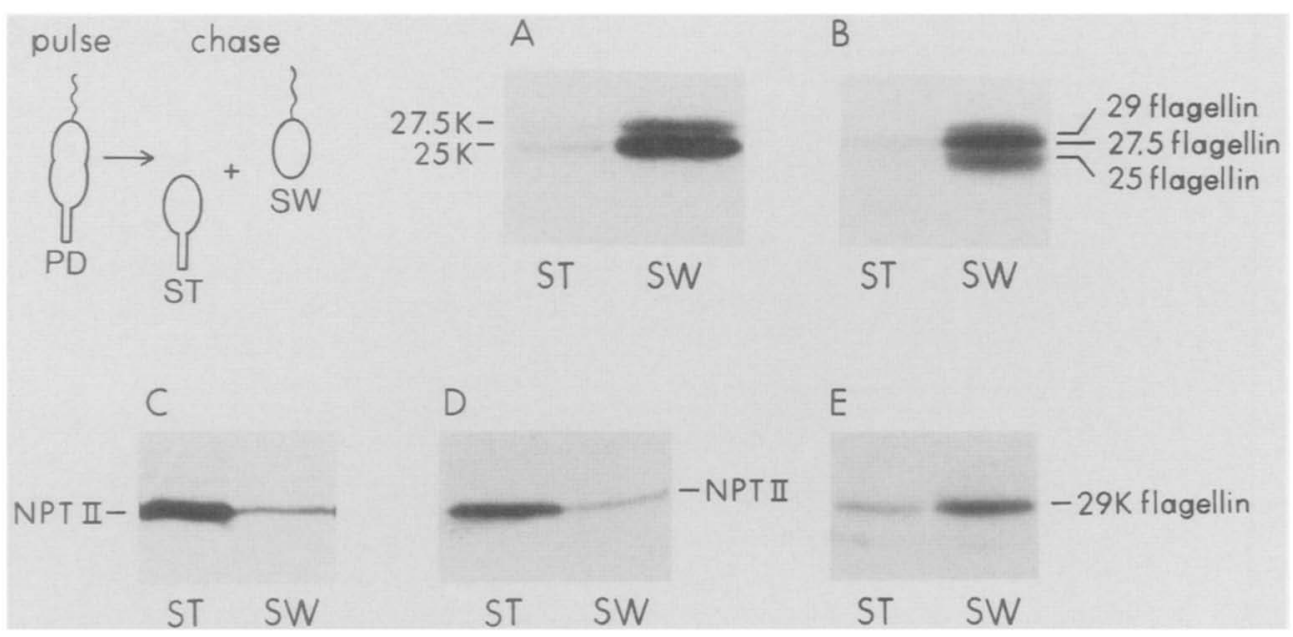

Figure 6. Autoradiograms of pulse-chase experiments in which predivisional cells (PD), shown schematically (top left), were pulselabeled with $\left.{ }^{35} \mathrm{~S}\right]$ methionine $(15 \mu \mathrm{Ci})$ for $20 \mathrm{~min}$ and then chased into progeny stalked $(\mathrm{ST})$ and swarmer (SW) cells. The progeny cells were separated and lysed, and the proteins were immunoprecipitated with anti-flagellin antibody $(A, B$, and $E)$ or anti-NPT II antibody $(C$ and $D)$. The immunoprecipitated proteins were separated by electrophoresis in $10 \%$ polyacrylamide-SDS gels. The $C$. crescentus strains used in each panel were CB15N $(A)$; AE9002/pRB3 $(B) ; \mathrm{CB} 15 \mathrm{~N} / \mathrm{pZL1451}(C)$; SC1997 (D); and AE8006 (E).

scopy of wild-type and $f l g /$ deletion strains suggests that in wild-type strains, the $29 \mathrm{~K}$ flagellin resides at the hook-filament junction (R. Bryan and A. Driks, unpubl.). The observation that strains carrying a deletion in the flgJ gene are able to assemble a flagellum and are motile clearly demonstrates that the $29 \mathrm{~K}$ flagellin is not essential for motility. We have recently determined, however, that $f l g /$ deletion strains form swarm colonies at a slower rate than those formed by isogenic wild-type strains. It remains to be determined whether flgJ deletion strains have fewer flagellum-bearing cells or whether the number of swarmer cells is comparable to wild type, but they swim more slowly.

\section{Asymmetric distribution of flagellar proteins}

The generation of different progeny cells from a binary fission requires the asymmetric distribution of proteins and structures in the predivisional cell and their ultimate segregation with the appropriate progeny cell. Asymmetric segregation of Caulobacter proteins has been described previously for the chemotaxis methylation machinery, which is positionally biased toward the portion of the predivisional cell that bears the flagellum (Gomes and Shapiro 1984), and several heat shock proteins, which segregate to the nonmotile stalked cell (Reuter and Shapiro 1987). In this paper we have addressed the possible mechanisms that contribute to the segregation of a flagellar protein to the progeny swarmer cell. We have shown that the newly synthesized $29 \mathrm{~K}$ flagellin segregates to the progeny swarmer cell upon division. Because the flagellins are the components of the flagellar filament, a possible mechanism for their segregation could rely on their assembly into the flagellum that is formed in the predivisional cell. Consequently, the flagellar components would then segregate to the swarmer cell upon division. This mechanism would require that most, if not all, flagellin monomers be assembled into the filament. However, even in mutant cells unable to assemble either a hook or a filament, the $29 \mathrm{~K}$ flagellin still segregated to the progeny cell that would have carried a flagellum. Because incorporation of the flagellar protein into the assembled structure did not appear to be required for segregation to the correct progeny cell, we asked if the reporter protein NPT II, whose transcription is driven by the flgl promoter region, was correctly positioned. NPT II that was synthesized in the predivisional cell was not segregated to the progeny cell in a specific manner. Therefore, the protein must carry signals for its proper segregation.

Positioning of a protein within the cell could be accomplished in a number of different ways: (1) The location of a gene on a chromosome could be important. It is possible that a gene encoding a protein that has to be positioned could be oriented and transcribed in such a way that upon its synthesis, the protein is near or at a specific membrane-binding site. This does not appear to be the case for the positioning of the $29 \mathrm{~K}$ flagellin. The gene for this protein can be located on a plasmid without altering its pattern of segregation. (2) Transcription could specifically come from that portion of the replicating chromosome that will ultimately reside in the swarmer portion of the predivisional cell. Because transcription and translation are coupled, the gene would be expressed at the site of residence of the protein. A possible way to initiate transcription from only one of the newly replicated regions of the chromosome could be to utilize the $5^{\prime}$ regulatory sequences as a binding site for a soluble factor present only in one part of the predivisional cell. Clearly, in the case of $29 \mathrm{~K}$ flagellin, the $5^{\prime}$ regulatory region is not the sole determining factor for its segregation to the swarmer cell because the NPT II gene product from the chimeric fusion gene was not preferentially segregated to the swarmer cell. (3) The 
mRNA could migrate to the correct portion of the predivisional cell, either because of a nascent polypeptide chain or because of properties inherent to the RNA itself. If the mRNA were localized in the swarmer cell portion of the predivisional cell, it is likely that the NPT II synthesized from the chimeric flgJ-NPT II mRNA in the predivisional cell would be segregated to the progeny swarmer cell. We did not find NPT II protein segregating to the swarmer cell. This could mean that the chimeric mRNA is not positioned in the predivisional cell. However, it is also possible that the flgJ-NPT II chimeric mRNA is confined to the swarmer portion of the predivisional cell but that the newly synthesized NPT II diffuses to the rest of the predivisional cell before division occurs. Milhausen and Agabian (1983) found that mRNA for the $25 \mathrm{~K}$ flagellin segregated to the daughter swarmer cell upon cell division, suggesting that mRNA segregation does occur in some cases. (4) The free flagellin protein could segregate by itself. We have shown that the $5^{\prime}$ regulatory sequences are not solely responsible for protein segregation. The possibility must therefore be considered that an amino acid sequence in the positioned protein is responsible for correct segregation. Furthermore, the site on the cell that "sees" this amino acid sequence cannot be the hook and filament but must be a receptor at or near the position of flagellar assembly. This putative receptor might be laid down at the site of cell division, as it is this site in both the swarmer and stalked cell that ultimately bears the flagellum. Experiments are in progress to define the portion of the protein-coding region that is essential for the proper segregation of the $29 \mathrm{~K}$ flagellin.

\section{Materials and methods}

Restriction enzymes were obtained from New England Biolabs and Boehringer-Mannheim. Calf intestine alkaline phosphatase, T4 polynucleotide kinase, and nuclease $\mathrm{S} 1$ were purchased from Boehringer-Mannheim. $\left[\gamma^{-32}\right.$ P]ATP $(10 \mathrm{Ci} / \mathrm{mmole})$ and $\left.{ }^{35} \mathrm{~S}\right]$ methionine $(1150 \mathrm{Ci} / \mathrm{mmole})$ were obtained from Amer- sham Corporation. Staph A cells were purchased from Bethesda Research Laboratory. RNA used for nuclease S1 assays was extracted with phenol at $65^{\circ} \mathrm{C}$, as described previously (Amemiya et al. 1980).

\section{Bacterial strains and growth conditions}

Bacterial strains and plasmids used in this study are listed in Tables 1 and 3, respectively. C. crescentus was grown at $30^{\circ} \mathrm{C}$ in minimal glucose M2 or in rich PYE media (Contreras et al. 1978|. C. crescentus wild-type CB15N and derivative strains were synchronized following the separation of swarmer cells in a Ludox density gradient, as reported by Evinger and Agabian (1977) and as described previously (Mansour et al. 1980). Motile colonies were detected on semisolid swarm plates containing $0.3 \%$ agar in PYE, as described previously (Bryan et al. 1984).

\section{Construction of AE9002 from SC512}

C. crescentus strain SC512 carries the spontaneous flaE156 deletion (Johnson et al. 1979; Purucker et al. 1982). AE9002 was constructed by genetically moving a region of SC512 DNA containing this deletion into the synchronizable, wild-type background of CB15N (Evinger and Agabian 1977). The first step in this construction was to mate AE5478 (cysD:: Tn5, ts104, pVS1) with $C B 15 N$. CB15N colonies that had obtained cys $D:: \operatorname{Tn} 5$ formed kanamycin-resistant $\left(\operatorname{Kan}^{\mathrm{r}}\right.$ progeny at $30^{\circ} \mathrm{C}$, the restrictive temperature for AE5478. The $\mathrm{Kan}^{\mathrm{r}}$ progeny were screened for the presence of a $\mathrm{Cys}^{-}$phenotype. Because cys $D$ and flaE can be cotransduced, one cysD : : Tn 5 CB15N derivative AE9001 was transduced to $\mathrm{Cys}^{+}$prototrophy, using the transducing phage 0Cr30 grown on strain SC512 (flaE156). Of 27 transductants tested, 10 had a $\mathrm{Fla}^{-}$phenotype. The plasmid pVS1, resident subsequent to the original mating, was cured from one $\mathrm{Fla}^{-}$transductant, AE9002, by growth of the strain in PYE liquid culture. To show that the deletion in SC512 had been transferred correctly to AE9002, DNA was isolated from SC512 and AE9002, digested with the restriction enzymes HindIII and BamHI, and analyzed by Southern blot hybridization using probe 1, shown in Figure 2. The same size restriction fragments were detected in the two strains /data not shown). Furthermore, the pattern of plasmid complementation was identical in the two strains.

The deletion in SC512 was shown previously to be approximately $3 \mathrm{~kb}$ in length (Purucker et al. 1982). Digestions of

Table 3. List of plasmids

\begin{tabular}{|c|c|c|c|}
\hline Plasmid & $\begin{array}{r}\text { Length } \\
(\mathrm{kbp})\end{array}$ & Relevant properties & Reference/source \\
\hline pBR322 & 4.4 & $\mathrm{Ap}^{\mathrm{R}}, \mathrm{Tc}^{\mathrm{R}}$ & Bolivar et al. (1977) \\
\hline pBR325 & 5.9 & $\mathrm{Ap}^{\mathrm{R}}, \mathrm{Tc}^{\mathrm{R}}, \mathrm{Cm}^{\mathrm{R}}$ & Bolivar (1978) \\
\hline pFB1 & 8.1 & $\mathrm{Ap}^{\mathrm{R}}, \mathrm{Cm}^{\mathrm{R}}, \mathrm{flg} /$ insert, $\mathrm{pBR} 325$ vector & Champer et al. (1985) \\
\hline pRB3 & 30 & $\mathrm{Tc}^{\mathrm{R}}$, flgl, flaE, flaY insert, $\mathrm{pRK} 290$ vector & Bryan et al. (1987) \\
\hline $\mathrm{pRB} 7$ & 23 & $\mathrm{Tc}^{\mathrm{R}}$, flaE, flaY insert, pRK290 vector & Bryan et al. (1987) \\
\hline pRK2013 & 49 & $\mathrm{Kn}^{\mathrm{R}}$, ColE1 replicon, $\operatorname{Tr}^{+}, \mathrm{RK} 2$ derivative & Figurski and Helinski (1979) \\
\hline pRK290 & 20 & $\mathrm{Tc}^{\mathrm{R}}, \mathrm{RK} 2$ replicon, $\operatorname{Tra}^{-}, \mathrm{mob}^{-}$, incompatibility group P-1 & Ditta et al. $(1980)$ \\
\hline pRK291 & 20 & $\mathrm{Tc}^{\mathrm{R}}, \mathrm{RK} 2$ replicon, $\mathrm{Tra}^{-}, \mathrm{mob}^{-}$, incompatibility group P-1 & Ditta et al. $(1985)$ \\
\hline pVS1 & 66 & $\mathrm{Tc}^{\mathrm{R}}, \mathrm{Kn}^{\mathrm{S}}$ derivative of $\mathrm{RP} 4$ & Barrett et al. (1982) \\
\hline pKM2 & 5.1 & $\mathrm{Ap}^{\mathrm{R}}, \mathrm{Kn}^{\mathrm{R}}$ & Beck et al. $(1982)$ \\
\hline pZL250 & 4.9 & $\mathrm{Ap}^{\mathrm{R}}$ & this study; derived from $\mathrm{pKM} 2$ \\
\hline pZL451 & 6.6 & $\mathrm{Ap}^{\mathrm{R}}, f l g /$ promoter insert, correct orientation & this study \\
\hline pZL452 & 6.6 & $\mathrm{Ap}^{\mathrm{R}}, \mathrm{flg} /$ promoter insert, incorrect orientation & this study \\
\hline pZL1451 & 26.6 & $\mathrm{Ap}^{\mathrm{R}}, \mathrm{Tc}^{\mathrm{R}}$ & derived from pZL451 \\
\hline pZL1452 & 26.6 & $\mathrm{Ap}^{\mathrm{R}}, \mathrm{Tc}^{\mathrm{R}}$ & derived from pZL452 \\
\hline
\end{tabular}


SC512 DNA with EcoRI and BamHI, as well as with EcoRI and HindIII, followed by Southern blot hybridization to probe 2 (Fig. 2A), indicated that the size of the deletion was approximately $3.4 \mathrm{~kb}$ (data not shown). The end points of this deletion were mapped by digesting SC512 DNA with PstI and SalI and analyzing the fragments by Southern blot hybridization. Following Pst I digestion, both probe 1 and probe 2 (Fig. 2A) hybridized to a fusion fragment of $4.6 \mathrm{~kb}$. This is consistent with either a 3.8$\mathrm{kb}$ deletion spanning all of the internal PstI sites, as shown in Fig. 2A, or with a $2.9-\mathrm{kb}$ deletion extending from the PstI site in flgl to the PstI site in flaY. When Southern hybridization of Sall-digested SC512 DNA was done, probe 2 hybridized to a $2.1-\mathrm{kb}$ fragment, slightly smaller than the 2.2-kb Sall fragment found in wild-type DNA. This size is consistent with what would be found if the deletion extended from flgK to flaY, as shown in Figure 2A. If the deletion extended only from the Pst I site in flgI to the PstI site in flaY, the Sall fragment in SC512 hybridizing to probe 2 would have been larger, not smaller, than the corresponding Sall fragment from the wild-type DNA.

\section{Immunoprecipitation}

The synthesis of the flagellins and NPT II was measured in cultures pulse-labeled with $\left.{ }^{35} \mathrm{~S}\right]$ methionine by the immunoprecipitation procedure described by Gomes and Shapiro (1984). $\left[{ }^{35} \mathrm{~S}\right]$ Methionine-labeled $C$. crescentus cells were lysed, preadsorbed with Staph A cells, and immunoprecipitated with antisera raised against purified flagellins (Shapiro et al. 1982) or NPT II (Champer et al. 1985). The immunoprecipitated proteins were separated by electrophoresis through $10 \%$ or $12 \%$ polyacrylamide-SDS gels. The gels were fixed, stained, enhanced, and subjected to autoradiography.

\section{S1 nuclease assay}

S1 nuclease assays were performed by a modification (Amemiya et al. 1986) of the procedure of Berk and Sharp (1977). The probes used were derived from the plasmid pRBl (Champer et al. 1985). This plasmid contains a 2.2-kb SalI fragment encoding the entire $\mathrm{flg} /$ gene. The PvuII-ClaI probe was obtained by phosphorylating the ClaI end with phage T4 polynucleotide kinase, redigesting the DNA with PvuII, and isolating the 0.8$\mathrm{kb}$ fragment by electrophoresis through a $5 \%$ (wt/vol) polyacrylamide gel. The NaeI-TaqI probe was prepared by 5 ' end-labeling the TaqI site, redigesting the DNA with NaeI, and isolating the 0.28 -kb fragment by electrophoresis through a $5 \%$ (wt/vol) polyacrylamide gel. The labeled fragment was then mixed with $100 \mu \mathrm{g}$ of RNA, precipitated with ethanol, and dried briefly under vacuum. Following hybridization and S1 digestion, the samples were analyzed on a $6 \%(\mathrm{wt} / \mathrm{vol})$ polyacrylamide gel with $7 \mathrm{M}$ urea, using $0.5 \times \mathrm{TBE}$ buffer (Maniatis et al. 1982). RNA was isolated from synchronized cultures, as described by Amemiya et al. (1980).

\section{Construction of NPT II transcription fusion}

A $1.7-\mathrm{kb}$ BamHI-Bcll fragment carrying the $f l g /$ promoter was ligated into the unique BgIII site of pZL250 (Fig. 4). pZL250 was made as follows: The small EcoRI-BamHI fragment of pBR322 was deleted, and a BglII site was manufactured in its place. The BglI-Sal fragment, containing the neo gene of Tn5, was then inserted in place of the BglII-Sall fragment of the pBR322 derivate. The resultant two plasmids, pZL451, where the direction of transcription is toward the neo gene, and pZL452, where direction of transcription is away from the neo gene, were cut at their respective unique EcoRI sites and ligated into the EcoRI site of pRK291. These recombinants, pZL1451 and pZL1452, were then mated into Caulobacter strains $\mathrm{CB} 15 \mathrm{~N}$ and AE9002.

\section{Acknowledgments}

This investigation was supported by U.S. Public Health Service grants GM-11301 and GM-32506 from the National Institutes of Health and Core Cancer Center grant NIH/NCI P30-CA13330. Z.G.L. received predoctoral support from National Institutes of Health training grant GM07491-06. The authors thank E. Beck for the plasmid pKM2.

\section{References}

Amemiya, K., B. Raboy, and L. Shapiro. 1980. Involvement of host RNA polymerase in the early transcription program of Caulobacter crescentus bacteriophage Cdl DNA. Virology 104: 109-116.

Amemiya, K., V. Bellofatto, L. Shapiro, and J. Feingold. 1986. In vitro and in vivo transcription initiation at a highly conserved promoter within a $16 \mathrm{~S}$ ribosomal RNA. I. Mol. Biol. 187: $1-14$.

Artishevsky, A., A. Grafsky, and A. Shiu Lee. 1985. Isolation of mammalian sequence capable of conferring cell cycle regulation to a heterologous gene. Science 230: 1061-1063.

Barrett, J.T., R.H. Croft, D.M. Ferber, C.J. Gerardot, P.V. Schonlein, and B. Ely. 1982. Genetic mapping with Tn5-derived auxotrophs of Caulobacter crescentus. I. Bacteriol. 151: 888-898.

Beck, E., G. Ludwig, E.A. Auerswald, B. Reiss, and H. Schaller. 1982. Nucleotide sequence and exact localization of the neomycin phosphotransferase gene from transposon Tn5. Gene 19: 327-336.

Berk, A.J. and P.A. Sharp. 1977. Sizing and mapping of early adenovirus mRNAs by gel electrophoresis of $\mathrm{S} 1$ endonuclease-digested hybrids. Cell 12: 721-732.

Bolivar, F. 1978. Construction and characterization of new cloning vehicles. III. Derivatives of plasmid pBR322 carrying unique EcoRI sites for selection of EcoRI-generated recombinant molecules. Gene 4: 121-136.

Bolivar, F., R.L. Rodrigues, P.J. Greene, M.C. Betlack, H.L. Heynecker, and H.W. Boyer. 1977. Construction and characterization of new cloning vehicles. II. A multipurpose cloning system. Gene 2: 95-113.

Bryan, R., M. Purucker, S.L. Gomes, W. Alexander, and L. Shapiro. 1984. Analysis of the pleiotropic regulation of flagellar and chemotaxis gene expression in Caulobacter crescentus using plasmid complementation. Proc. Natl. Acad. Sci. 81: $1341-1345$.

Bryan, R., R. Champer, S.L. Gomes, B. Ely, and L. Shapiro. 1987. Separation of temporal control and trans-acting modulation of flagellin and chemotaxis genes in Caulobacter. Mol. Gen. Genet. 206: 303-306.

Champer, R., A. Dingwall, and L. Shapiro. 1987. Cascade regulation of Caulobacter flagellar and chemotaxis genes. I. Mol. Biol. 194: 71-80.

Champer, R., R. Bryan, S.L. Gomes, M. Purucker, and L. Shapiro. 1985. Temporal and spatial control of flagellar and chemotaxis gene expression during Caulobacter cell differentiation. Cold Spring Harbor Symp. Quant. Biol. 50: 831840.

Chen, L.-S., D. Mullin, and A. Newton. 1986. Identification, nucleotide sequence, and control of developmentally-regulated promoters in the hook operon region of Caulobacter crescentus. Proc. Natl. Acad. Sci. 83: 2860-2864. 
Contreras, I., L. Shapiro, and S. Henry. 1978. Membrane phospholipid composition of Caulobacter crescentus. I. Bacteriol. 135: 1130-1136.

Ditta, G., S. Stanfield, D. Corbin, and D.R. Helinski. 1980. Broad host range DNA cloning system for gram-negative bacteria: Construction of a gene bank of Rhizobium melioti. Proc. Natl. Acad. Sci. 77: 7347-7351.

Ditta, G., T. Schmidhauser, P.L. Yakobson, X. Liang, D.R. Finlay, D. Quiney, and D.R. Helinski. 1985. Plasmids related to the broad host range vector pRK290 useful for gene cloning and for monitoring gene expression. Plasmid 13: $149-153$.

Ely, B., R.H. Croft, and C.J. Gerardot. 1984. Genetic mapping of genes required for motility in Caulobacter crescentus. Genetics 108: 523-532.

Ely, B., C.J. Gerardot, P. Frederikse, S.L. Gomes, and L. Shapiro. 1986. General non-chemotactic mutants of Caulobacter crescentus. Genetics 114: 717-730.

Evinger, M. and N. Agabian. 1977. Envelope-associated nucleoid from Caulobacter crescentus stalked and swarmer cells. J. Bacteriol. 132: 294-301.

Figurski, D.H. and D.R. Helinski. 1979. Replication of an origin containing derivative of plasmid RK2 dependent on a plasmid function provided in trans. Proc. Natl. Acad. Sci. 76: $1648-1652$.

Gill, P. and N. Agabian. 1982. A comparative structural analysis of the flagellin monomers of Caulobacter crescentus indicates that these proteins are encoded by two genes. $J$. Bacteriol. 150: 925-933.

Gill, P. and N. Agabian. 1983. The nucleotide sequence of $\mathrm{M}_{\mathrm{r}}-28,500$ flagellin gene of Caulobacter crescentus. I. Biol. Chem. 258: 7395-7401.

Gomes, S.L. and L. Shapiro. 1984. Differential expression and positioning of chemotaxis methylation proteins in Caulobacter. J. Mol. Biol. 178: 551-568.

Huguenel, E. and A. Newton. 1984. Isolation of flagellated membrane vesicles from Caulobacter crescentus cells: Evidence for functional differentiation of polar membrane domains. Proc. Natl. Acad. Sci. 81: 3409-3413.

Johnson, R., J. Walsh, B. Ely, and L. Shapiro. 1979. Flagellin hook and basal complex of Caulobacter crescentus. I. Bacteriol. 138: 984-989.

Koyasu, S., M. Asada, A. Fukuda, and Y. Okada. 1981. Sequential polymerization of flagellin A and flagellin B into Caulobacter flagella. J. Mol. Biol. 153: 471-475.

Lagenaur, C. and N. Agabian. 1978. Caulobacter flagella organelle: Synthesis, compartmentation, and assembly. I. Bacteriol. 135: 1062-1069.

Maniatis, T., E.F. Fritsch, and J. Sambrook. 1982. Molecular cloning: A laboratory manual; p. 454. Cold Spring Harbor Laboratory, Cold Spring Harbor, New York.

Mansour, J., S. Henry, and L. Shapiro. 1980. Differential membrane synthesis during the cell cycle of Caulobacter crescentus. J. Bacteriol. 141: 262-269.

Milhausen, M. and N. Agabian. 1983. Caulobacter flagellin mRNA segregates asymmetrically at cell division. Nature 302: $630-632$.

Milhausen, M., P. Gill, G. Parker, and N. Agabian. 1982. Cloning of developmentally-regulated flagellin genes from Caulobacter crescentus via immunoprecipitation of polyribosomes. Proc. Natl. Acad. Sci. 79: 6847-6851.

Minnich, S.A. and A. Newton. 1987. Promoter mapping and cell cycle regulation of flagellin gene transcription in Caulobacter crescentus. Proc. Natl. Acad. Sci. 84: 1142.

Nathan, P., S.L. Gomes, K. Hahnenberger, A. Newton, and L. Shapiro. 1986. Differential localization of membrane re- ceptor chemotaxis proteins in the Caulobacter predivisional cell. I. Mol. Biol. 191: 433-440.

Osley, M.A., J. Gould, S. Kim, M. Kane, and L. Hereford. 1986. Identification of sequences in a yeast histone promoter involved in periodic transcription. Cell 45: 537-544.

Poindexter, J.S. 1964. Biological properties and classification of the Caulobacter group. Bacteriol. Rev. 28: 231.

Purucker, M., R. Bryan, K. Amemiya, B. Ely, and L. Shapiro. 1982. Isolation of a Caulobacter gene cluster specifying flagellin production by using non-motile Tn5 insertion mutants. Proc. Natl. Acad. Sci. 79: 6797-6801.

Reuter, S. and L. Shapiro. 1987. Asymmetric segregation of heat-shock proteins upon cell division in Caulobacter crescentus. J. Mol. Biol. (in press).

Shapiro, L., J. Mansour, P. Shaw, and S. Henry. 1982. Synthesis of specific membrane proteins is a function of DNA replication and phospholipid synthesis in Caulobacter crescentus. J. Mol. Biol. 159: 303-322.

Stallmeyer, M.J.B., D. DeRosier, S.I. Aizawa, R.M. Macnab, K. Hahnenberger, and L. Shapiro. 1985. Structural studies of the basal body of bacterial flagella. Biophys. J. 47: 48a.

Wagenknecht, T., D. DeRosier, L. Shapiro, and A. Weissborn. 1981. Three-dimensional reconstruction of the flagellar hook from Caulobacter crescentus. I. Mol. Biol. 151: 439465.

Weissborn, A., H.M. Steinman, and L. Shapiro. 1982. Characterization of the proteins of the Caulobacter crescentus flagellar filament: Peptide analysis and filament organization. I. Biol. Chem. 257: 2066-2074. 


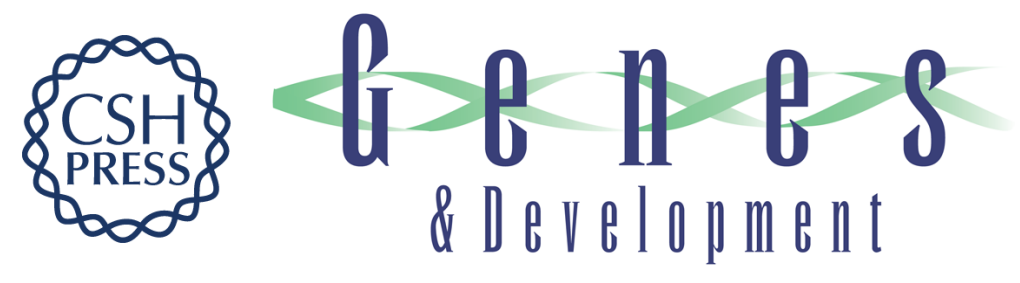

\title{
Control of synthesis and positioning of a Caulobacter crescentus flagellar protein.
}

\author{
Z G Loewy, R A Bryan, S H Reuter, et al.
}

Genes Dev. 1987, 1:

Access the most recent version at doi:10.1101/gad.1.6.626

$\begin{array}{ll}\text { References } & \begin{array}{l}\text { This article cites } 39 \text { articles, } 22 \text { of which can be accessed free at: } \\ \text { http://genesdev.cshlp.org/content/1/6/626.full.html\#ref-list-1 }\end{array}\end{array}$

License

Email Alerting Receive free email alerts when new articles cite this article - sign up in the box at the top Service right corner of the article or click here.

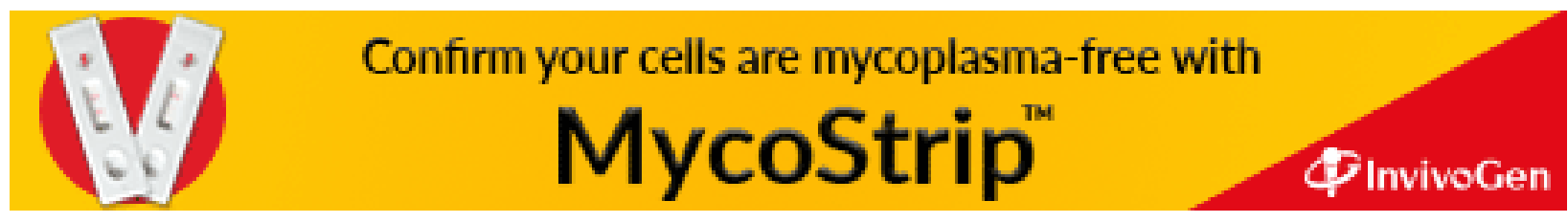

